\title{
Motives for coffee consumption at coffee shops in Mexico
}

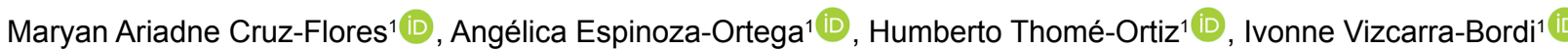

${ }^{1}$ Universidad Autónoma del Estado de México, Instituto de Ciencias Agropecuarias y Rurales, Toluca Estado de México, México

Contact authors: hinata_x_rid@hotmail.com, angelica.cihuatl@gmail.com, aespinozao@uaemex.mx,hthomeo@uaemex.mx,vizcarrab@uaemex.mx

Received in April 28, 2020 and approved in July 29, 2020

\begin{abstract}
Coffee is one of the main sources of foreign exchange for developing countries. Mexico accounts only $2.68 \%$ of the world coffee production, but represent the most important source of foreign exchange in the agricultural sector. The Mexican coffee began to be recognized in recent years, and despite the increase of the consumption, Mexico is not considered an important consumer. The objective was to analyse the motives for coffee consumption at coffee shops with quality labels. A national and a transnational company were selected in central Mexico to carry out a total of 600 questionnaires. The questionnaire had four sections: frequency of consumption, Food Choice Questionnaire (FCQ), some images of coffee quality labels, and a socio-economic. The data were analysed using multivariate statistics, factor and cluster analysis. Indifferent, Pragmatic and Hedonic-Dependent consumers were identified; who are mostly young and middle-aged, single, childless and college educated. Their interest in attending coffee shops is to socialize; they are not interested in quality labels which have negative implications for the use of this type of labels in Mexico.
\end{abstract}

Key words: Consumers; food choice questionnaire; factor and cluster analysis.

\section{INTRODUCTION}

Research on consumers started in the year 1950 (Shiffman; Lazar; Wisenblit, 2010), but it is until recent decades that the number studies on the motivations, perceptions and emotions of consumers started to increase (Meiselman, 2015), largely due the increase in the quantity and variety of food products that appear on the market in response to a more demanding consumer (Clemons, 2008).

Consumers may show different preference patterns for the same product, depending on their different hedonic responses. Groups of consumers that share a certain hedonic pattern are known as consumer segments (Varela; Beltrán; Fiszman, 2014); these segments are defined by the type of product and by the extrinsic and intrinsic factors that influence choice (Pieniak et al., 2009).

It is certainly of great importance to understand how consumers perceive a product and how their opinions are linked to that perception (Masson et al., 2016). Many studies on consumer preferences use a method that focuses on only one product (Jiang; King; Prinyawiwatkul, 2014; Meiselman, 2015). That is the case of the present work, which considers only the coffee.

According to the International Coffee Organization (ICO), coffee has been one of the most valuable primary products for many years, surpassed only by oil as a source of foreign exchange for developing countries. Mexico produces 234,000 kilograms of coffee, mostly produced by small-scale producers (ICO, 2015). This amounts to $2.68 \%$ of world production, making Mexico the ninth largest producer of coffee.

In terms of national production, coffee is the main source of foreign exchange in the Mexican agricultural sector
(SAGARPA, 2015). In this regard, Linton (2003) mentions, that the use of quality labels for coffee helps small producers to maintain their livelihoods while producing a quality product.

The Mexican tradition of coffee production started to be recognized in recent years, thanks to which Mexican coffee can now use some quality labels, such as Denomination of Origin for Veracruz and Chiapas (IMPI, 2000; 2003), Fair Trade label, and the Organic Coffee label (USDA, 2014). México is one of the main organic coffee producers worldwide (Jurjonas et al., 2016), 63.02\% of the organic coffee produced is exported (ICO, 2015).

Despite being recognized as a producer of quality coffee, Mexico is not considered an important coffee consumer. Nevertheless, the consumption of coffee has increased at an annual rate of $2.3 \%$ in recent years (SAGARPA, 2015), to a large extent due to the arrival of global brands, which have helped increase coffee consumption from 1.1 to $1.7 \mathrm{~kg}$ per capita over a period of ten years (SAGARPA, 2015; ICO, 2015).

Global brands use a series of quality labels that are imitated by Mexican companies; however, it is not known if the Mexican consumers are aware of these labels and if they actually look for them. This is important because, as Linton (2003) notes, changes in consumer preferences are fundamental for the transformation of institutional practices and, therefore, production processes.

Authors such as Macchione and Eugênio (2006) mention that the differential attributes of coffee involve a wide range of concepts such as tradition, superior quality drink, environmental preservation and social responsibility. In this regard, Guerrero et al. (2009) mention that a quality label is an information signal that may work best if it communicates something meaningful and relevant from the consumer's point of view. 
FAO (2002) states that quality labels establish categories that coincide with the need to protect productive and culinary traditions and the authenticity of products, and that they promote a type of agriculture that respects the environment. In other words, these labels respond to increased consumer awareness about environmental and ethical issues (Kang et al., 2012; Jang; Kim; Lee, 2015).

However, these consumer sensitivities have been defined based on studies carried out in developed countries (Fotopoulos et al., 2008; Guerrero et al., 2009; Pieniak et al., 2009; Elorriaga et al., 2012; Masson et al., 2016), and there are very few studies on consumers in developing countries. Pioneer studies on the importance of quality labels in Mexico such as Espinoza-Ortega et al. (2016) have identified a lack of interest in the consumption of food with some type of recognized value, which has negative implications for the implementation of quality labels. Further studies should be carried out on specific products with quality labels, like coffee.

Most of the studies that have been done on the behaviour of coffee consumers have focused on economic aspects (Giovannucci; Liu; Byers, 2008; Eckhardt; Belk; Devinney, et al., 2010; Aragón et al., 2013; Donovan; Pole, 2013); others on health issues (González; Ramírez, 2014; Schubert et al., 2014; Sunarharum; Williams; Smyth, 2014); and some others on coffee quality (Gotow et al., 2015).

Although these studies are necessary to understand the dynamics of coffee markets and their effects, they do not allow to understand the motivations of consumers in Mexico, who are the last link of the productive chain and whose decisions are crucial in product valuation processes (Lipton, 2003). Therefore, the objective of this study was to analyse the motives for coffee consumption at coffee shops with quality labels.

\section{MATERIAL AND METHODS}

The study was carried out in the three of the most important cities of central Mexico (Mexico City, Puebla and Toluca) (Negrete, 2010; Ibarra, 2010). First al all, was investigated via the Internet the leading companies in those cities that sell coffee in cups, the type of service that offered, the characteristics of the coffee and the type of quality label that have (denomination of origin, fair trade, organic or linked to a specific territory). Five companies were identified, one transnational company and four national ones, but only two offered coffee with the following labels: Fair Trade, Organic, Denomination of Origin and Territorial Link, one national and the transnational company; both were selected to carry out the interviews.

A total of 600 consumers were interviewed, the sample size complies with the rules established for Cluster analysis (Field, 2009) and infinite populations (Aguilar, 2005; Anderson; Sweeney; Williams, 2008; Martínez, 2014). Aragón (2013) recommends studying the behaviour of consumers of coffee with social and environmental attributes, in the places where consumers buy and consume the product and at the time of purchase and consumption; then, the questionnaires were applied face to face to consumers at the coffee shops. A convenience sampling was carried out, the criteria to select them were they were consuming coffee at the time and were interested and available to participate in the study.

The questionnaire had four sections. The first focused on the frequency of consumption (Aragón, 2013; De Oliveira et al., 2012). The second was based on the Food Choice Questionnaire (FCQ), originally designed by Steptoe, Pollard and Wardle (1995), which assessed ten variables: 1) Place of Consumption; 2) Mood; 3) Sensory Attractiveness; 4) Forms of consumption; 5) Price; 6) Health; 7) Loyalty towards a brand; 8) Territorial Aspects; 9) Ethical Aspects; and 10) Practicality (Table 1). Each variable was assessed with three items that were graded on a Likert scale from one to five: $1=$ Never; 2 = Almost never; 3 = Sometimes; .4 = Almost always; 5 = Always) (Kang et al., 2012; Tumanan; Lansangan, 2012; Varela; Beltrán; Fiszman, 2014; Gaviglio et al., 2014; Asioli et al., 2015; Labbe et al., 2015).

Section three consisted of four images of quality labels for coffee sold in the Mexican market Denomination of origin (Veracruz), Rain Forest, Fair trade, and Made in Mexico (Figure 1). The consumers were asked to identify the seals.

The last section focused on socio-economic aspects: sex, age, level of education, occupation, marital status, number of children and monthly income (Fotopoulos et al., 2009; Asioli et al., 2015; Jang; Kim; Lee, 2015; Lange et al., 2015; Van Loo et al., 2015).

The information was analysed using multivariate statistics. An exploratory factor analysis with Varimax rotation was performed to identify and determine the relationship between the items. The analysis considered all values higher than one and the percentage of total variability explained. Only 28 of the 30 items in the Food Choice Questionnaire were used, the ones that contributed the most to the explained variance of the model. The Kaiser-Meyer-Olkin index was used as a measure of sample adequacy, which was 0.728 , an acceptable value for factor analysis (Field, 2009).

The factor loads obtained as a result of the factor analysis were used to perform a Cluster analysis to identify consumer groups through the Ward method, in which the Euclidean distance is used as grouping algorithm for individuals and groups (Hair et al., 2009). A Kruskal Wallis analysis was performed to determine the differences between groups for each factor. The consumer groups were named based on this.

Descriptive statistics were used to compare the socioeconomic information, the characteristics of coffee consumption and the knowledge about labels of each of the identified groups. All statistical analyses were performed using the statistical package Statgraphics Centurion X (2015). 
Table 1: Variables and items used in the questionnaire.

\section{Variable}

1) Place of consumption

2) Mood

3) Sensory attractiveness

4) Forms of consumption

5) Price

6) Health

7) Loyalty

8) Territorial

9) Ethical Aspects

10) Practicality
Item

I buy coffee in a cup only in coffee shops

I buy coffee in supermarkets and prepare it at home

I consume coffee in self-service stores +

I consume coffee because it keeps me from being sleepy

I consume coffee when I am nostalgic

Coffee helps me to be active during the day

I consume coffee for its taste

I appreciate coffee with body

I choose a coffee for its aroma

I prefer to consume it black (no sugar, no milk, etc.)

I consume coffee with flavourings *

I consume coffee in mixed beverages (mocha, cappuccino, cream, etc.) *

I'm willing to pay more for specialty coffees

I buy expensive coffees because they are of better quality

I prefer cheap coffees *

Consuming coffee gives me gastritis

I consume coffee because it is good for my health *+

Consuming coffee alters my nerves

I consume coffee by family tradition

I like to explore different varieties of coffee *

I tend to always consume the same brand of coffee

I am interested in the region of origin of the coffee I consume

I prefer coffee with denomination of origin

I only consume coffee from Veracruz and Chiapas

I look for the Fairtrade label

I consume coffees bearing the Organic label

I consume coffees bearing the Rain Forest label

I consume coffee because it is easy to prepare

I consume coffee because I can easily find it

It combines easily with other foods

* Items with inverse score.

+ Items eliminated after factor analysis.

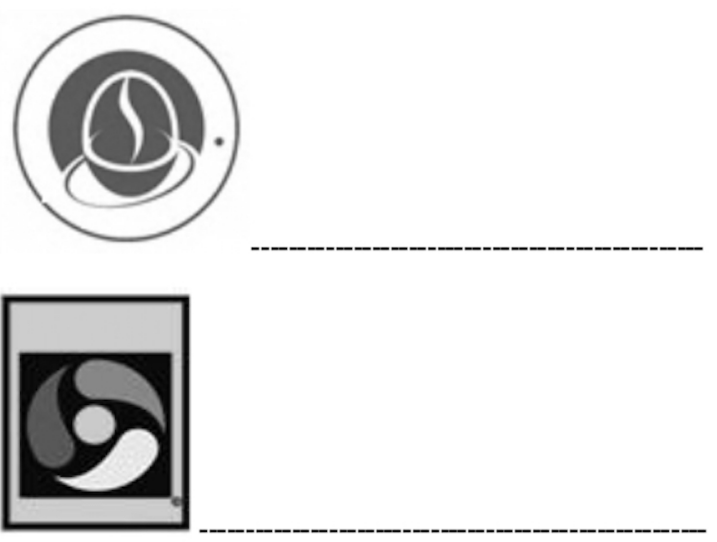

Figure 1: Quality labels of coffee in Mexico.

\section{RESULTS}

Nine factors were identified that explain $57.4 \%$ of the cumulative variance with a KMO of 0.728 (are show at Table 2 and

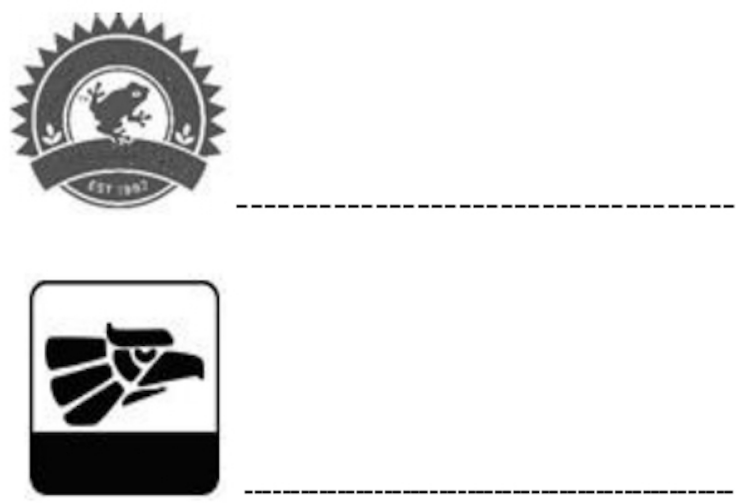

factorial load at Table 3). These factors were named according to the items considered by each of them (Table 3 ).

Factor 1. Territorial recognition and quality labels. The items considered by this factor are interest in the region of 
origin of the coffee, the consumption of coffee from Veracruz and Chiapas, and the consumption of coffee with the Fair Trade, Rain Forest and Organic labels.

Factor 2. Hedonism over health. This is the factor that includes the largest number of items. Of these, the items that received the highest score were: buying coffee only in coffee shops, consuming it for its taste, for the appreciation of the coffee's body and preference for cheap coffees (inverse score). The items in this factor that received a lower score were: consumption of coffee generates gastritis and nervous alterations.

Factor 3. Practicality. This factor consists of the following items: consumption of coffee because it can be easily prepared and easily found, and buying coffee in supermarkets to prepare at home.

Table 2: The factorial loads of each item.

\begin{tabular}{|c|c|c|c|c|c|c|c|c|c|}
\hline \multirow{2}{*}{ Item } & \multicolumn{9}{|c|}{ Factor } \\
\hline & 1 & 2 & 3 & 4 & 5 & 6 & 7 & 8 & 9 \\
\hline $\begin{array}{l}\text { I buy coffee in a cup } \\
\text { only in coffee shops }\end{array}$ & 0.281034 & 0.365322 & -0.274909 & -0.0050358 & 0.27188 & 0.201626 & 0.0996199 & 0.174097 & -0.255803 \\
\hline $\begin{array}{l}\text { I consume coffee } \\
\text { because it keeps me } \\
\text { from being sleepy }\end{array}$ & 0.11555 & -0.037021 & 0.0173469 & -0.0789864 & 0.665838 & 0.075157 & 0.202585 & 0.107566 & 0.159005 \\
\hline $\begin{array}{l}\text { I consume coffee for its } \\
\text { taste }\end{array}$ & -0.160961 & 0.504606 & -0.0034959 & 0.298435 & 0.248003 & -0.171402 & 0.101091 & 0.20329 & -0.223861 \\
\hline $\begin{array}{l}\text { I prefer to consume } \\
\text { it black (no sugar, no } \\
\text { milk) }\end{array}$ & 0.149119 & 0.149694 & -0.139284 & 0.216177 & 0.155231 & -0.145005 & 0.610782 & -0.087229 & -0.0083328 \\
\hline $\begin{array}{l}\text { I'm willing to pay more } \\
\text { for specialty coffees }\end{array}$ & 0.0515071 & -0.039757 & 0.0693295 & 0.373587 & -0.128493 & 0.508569 & 0.234787 & -0.134397 & 0.164217 \\
\hline $\begin{array}{c}\text { Consuming coffee gives } \\
\text { me gastritis }\end{array}$ & 0.0147262 & -0.443927 & -0.111693 & 0.165372 & 0.0783451 & 0.259807 & 0.371607 & -0.210733 & 0.335932 \\
\hline $\begin{array}{l}\text { I consume coffee by } \\
\text { family tradition }\end{array}$ & 0.028163 & -0.12792 & -0.0709614 & 0.0739773 & 0.151382 & 0.130889 & -0.0198564 & 0.169892 & 0.727403 \\
\hline $\begin{array}{l}\text { I am interested in the } \\
\text { region of origin of the } \\
\text { coffee I consume }\end{array}$ & 0.431362 & 0.193096 & -0.137149 & 0.289281 & 0.226524 & -0.0392073 & -0.193409 & 0.132574 & 0.342017 \\
\hline $\begin{array}{l}\text { I look for the Fairtrade } \\
\text { label }\end{array}$ & 0.754643 & 0.0226746 & 0.152083 & 0.0441936 & 0.05663 & 0.0823837 & -0.0309192 & -0.143098 & 0.182377 \\
\hline $\begin{array}{l}\text { I consume coffee because } \\
\text { it is easy to prepare }\end{array}$ & 0.0592599 & -0.066783 & 0.808354 & -0.131695 & 0.047305 & 0.0390782 & 0.0224158 & -0.0672655 & 0.054178 \\
\hline $\begin{array}{l}\text { I buy coffee in } \\
\text { supermarkets and } \\
\text { prepare it at home }\end{array}$ & -0.147658 & 0.0031462 & 0.734911 & 0.0668547 & -0.0880856 & -0.110531 & -0.0012436 & 0.230346 & 0.0070027 \\
\hline $\begin{array}{l}\text { I consume coffee when I } \\
\text { am nostalgic }\end{array}$ & 0.112496 & -0.025525 & 0.185184 & -0.112101 & 0.0061232 & 0.147824 & 0.627139 & 0.0881418 & 0.0230343 \\
\hline $\begin{array}{l}\text { I appreciate coffee with } \\
\text { body }\end{array}$ & 0.0222626 & 0.614406 & -0.0701564 & 0.069558 & 0.0220349 & 0.0946294 & 0.247236 & -0.0249391 & 0.0428226 \\
\hline $\begin{array}{c}\text { I consume coffee with } \\
\text { flavourings } *\end{array}$ & 0.0390494 & 0.0194753 & -0.140465 & 0.159752 & -0.0595291 & -0.698065 & 0.0034117 & -0.0549392 & 0.137772 \\
\hline $\begin{array}{c}\text { I buy expensive coffees } \\
\text { because they are of } \\
\text { better quality }\end{array}$ & 0.157265 & 0.0732865 & -0.0762627 & 0.0232506 & 0.0132206 & 0.689971 & 0.018544 & 0.0826325 & 0.110802 \\
\hline $\begin{array}{l}\text { I like to explore different } \\
\text { varieties of coffee } *\end{array}$ & -0.033024 & -0.159019 & 0.132369 & -0.723693 & -0.159544 & -0.0068276 & -0.0812515 & -0.0581011 & -0.04312 \\
\hline $\begin{array}{c}\text { I prefer coffee with } \\
\text { denomination of origin }\end{array}$ & 0.316614 & -0.045899 & -0.0129462 & 0.69675 & -0.0726356 & -0.0287506 & -0.0605513 & 0.0784839 & 0.0554687 \\
\hline $\begin{array}{l}\text { I consume coffees } \\
\text { bearing the Organic label }\end{array}$ & 0.590256 & -0.0724571 & 0.0655784 & 0.413275 & -0.101687 & 0.065762 & 0.149492 & -0.121044 & -0.0973814 \\
\hline
\end{tabular}


Table 2: Continuation.

\begin{tabular}{ccccccccccc}
\hline $\begin{array}{c}\text { I consume coffee because } \\
\text { I can easily find it }\end{array}$ & 0.0878806 & -0.135073 & $\mathbf{0 . 6 1 0 9 1 6}$ & -0.0527167 & 0.112429 & 0.206807 & 0.0073015 & -0.0952451 & -0.217344 \\
\hline $\begin{array}{c}\text { Coffee helps me to be } \\
\text { active during the day }\end{array}$ & -0.002916 & -0.0004661 & 0.0652862 & 0.0974218 & $\mathbf{0 . 8 0 2 6 9 6}$ & -0.0084311 & -0.0186339 & -0.0935016 & -0.0129558 \\
\hline $\begin{array}{c}\text { I choose a coffee for its } \\
\text { aroma }\end{array}$ & -0.017448 & 0.281813 & -0.0454394 & 0.443627 & $\mathbf{0 . 4 7 2 2 8}$ & -0.0244544 & -0.0399738 & 0.0151777 & -0.0970371 \\
\hline $\begin{array}{c}\text { I consume coffee in } \\
\text { mixed beverages (mocha, }\end{array}$ & 0.0861165 & 0.22387 & -0.0220163 & -0.108428 & -0.189246 & -0.416102 & 0.191796 & -0.0270913 & $\mathbf{0 . 5 4 1 9 5 9}$ \\
$\begin{array}{c}\text { cappuccino, cream, etc.) } \\
\text { I prefer cheap coffees * }\end{array}$ & -0.009218 & $\mathbf{0 . 5 7 0 2 0 2}$ & -0.415115 & 0.101981 & -0.0155361 & -0.0113078 & -0.1156 & -0.106893 & 0.0822296 \\
\hline $\begin{array}{c}\text { Consuming coffee alters } \\
\text { my nerves }\end{array}$ & 0.118446 & $\mathbf{- 0 . 5 8 9 1 5 2}$ & -0.0225978 & 0.012338 & 0.0741448 & 0.0238053 & 0.427483 & 0.206611 & -0.0128993 \\
\hline $\begin{array}{c}\text { I tend to always } \\
\text { consume the same brand } \\
\text { of coffee }\end{array}$ & 0.127198 & -0.272607 & 0.096498 & -0.0167104 & -0.196722 & -0.0709907 & 0.147928 & $\mathbf{0 . 6 5 7 9 2 9}$ & 0.0848371 \\
\hline $\begin{array}{c}\text { I only consume coffee } \\
\text { from Veracruz and } \\
\text { Chiapas }\end{array}$ & $\mathbf{0 . 5 7 2 1 0 3}$ & -0.124874 & -0.111537 & 0.0602045 & 0.051524 & 0.0124032 & 0.277953 & 0.409144 & 0.0169557 \\
\hline $\begin{array}{c}\text { I consume coffees } \\
\text { bearing the Rain Forest } \\
\text { label }\end{array}$ & $\mathbf{0 . 7 1 1 1 2 3}$ & -0.0547946 & -0.100757 & 0.0464571 & 0.0467294 & 0.0387604 & 0.201676 & 0.231335 & -0.0730203 \\
\hline $\begin{array}{c}\text { It combines easily with } \\
\text { other foods }\end{array}$ & 0.011942 & 0.170754 & 0.0162086 & 0.115868 & 0.175189 & 0.185343 & -0.136269 & $\mathbf{0 . 5 9 8 4 8 9}$ & 0.089858 \\
\hline
\end{tabular}

Table 3: Name of the obtained factors and their corresponding variance.

\begin{tabular}{cccc}
\hline Factor & Name & \% of variance & \% of cumulative variance \\
\hline 1 & Recognition of the territory of origin and quality labels & 12.7 & 12.7 \\
2 & Hedonism over health & 10.4 & 23.1 \\
3 & Practicality & 6.8 & 29.9 \\
4 & Denomination of origin & 5.6 & 35.5 \\
5 & Stimulating function & 5.0 & 40.4 \\
6 & Prestige & 4.8 & 45.2 \\
7 & Black coffee and nostalgia & 4.5 & 49.7 \\
8 & Conservative taste & 3.9 & 53.6 \\
9 & Traditional consumption and preference for mixed coffee beverages & 3.8 & 57.4 \\
\hline
\end{tabular}

Factor 4. Denomination of origin. This factor has only two items: a higher preference for coffee with denomination of origin, and a low score for the exploration of different varieties (inverse score).

Factor 5. Stimulating function. The items of this factor are consumption of coffee to avoid sleepiness, to be active during the day and choosing it because of its aroma.

Factor 6. Prestige. This factor consisted of preference for expensive coffees and willingness to pay more for specialty coffees, both of which received high scores, and consumption of coffee with flavourings, which had low scores (inverted score).

Factor 7. Black coffee and Nostalgia. This factor consists of the items related to the consumption of coffee without sugar or flavourings and to the consumption of coffee when the consumer feels nostalgic.

Factor 8. Conservative taste. This factor considers the custom of consuming the same brand of coffee and the decision to consume it because it can be easily combined with other foods.

Factor 9. Traditional consumption and preference for mixed beverages. This factor considers the consumption of coffee by family tradition and its consumption in mixed beverages such as mocha, cappuccino and cream, among others.

The cluster analysis identified three consumer groups (Table 4), which were named: Indifferent, Pragmatic and Hedonic Dependent. Table 4 shows the statistically significant differences among the nine factors analysed. 
Table 4: Comparative analysis of the identified groups.

\begin{tabular}{|c|c|c|c|c|c|c|c|}
\hline \multirow{2}{*}{ Name of the factor } & \multicolumn{2}{|c|}{ Indifferent $(\mathrm{n}=173)$} & \multicolumn{2}{|c|}{ Pragmatic $(n=178)$} & \multicolumn{2}{|c|}{ Hedonic dependent $(n=249)$} & \multirow[t]{2}{*}{$\mathrm{P}$} \\
\hline & Median & IQR & Median & IQR & Median & IQR & \\
\hline Recognition of territory of origin and labels & $1.80^{\mathrm{a}}$ & 1.00 & $3.00^{\mathrm{b}}$ & 0.90 & $3.00^{\mathrm{b}}$ & 1.20 & 0.001 \\
\hline Hedonism over health & $2.83^{\mathrm{a}}$ & 0.58 & $3.00^{\mathrm{b}}$ & 0.66 & $3.33^{\mathrm{c}}$ & 0.66 & 0.001 \\
\hline Practicality & $3.00^{\mathrm{a}}$ & 1.30 & $3.67^{\mathrm{b}}$ & 1.66 & $2.67^{\mathrm{c}}$ & 1.33 & 0.001 \\
\hline Denomination of origin & $3.00^{\mathrm{a}}$ & 0.50 & $3.00^{\mathrm{b}}$ & 1.00 & $3.00^{\mathrm{a}}$ & 0.50 & 0.017 \\
\hline Stimulating function & $2.67^{\mathrm{a}}$ & 1.00 & $3.00^{\mathrm{b}}$ & 1.30 & $3.67^{\mathrm{c}}$ & 1.00 & 0.001 \\
\hline Prestige & $2.67^{\mathrm{a}}$ & 0.66 & $3.00^{\mathrm{b}}$ & 1.00 & $3.00 \mathrm{a}^{\mathrm{b}}$ & 0.66 & 0.001 \\
\hline Black coffee and nostalgia & $2.00^{\mathrm{a}}$ & 1.50 & $3.00^{\mathrm{b}}$ & 1.50 & $3.00^{\mathrm{c}}$ & 1.50 & 0.001 \\
\hline Conservative taste & $3.00^{\mathrm{a}}$ & 1.00 & $3.00^{\mathrm{b}}$ & 1.50 & $3.00^{\mathrm{b}}$ & 1.00 & 0.001 \\
\hline $\begin{array}{l}\text { Traditional consumption and preference for } \\
\text { mixed beverages }\end{array}$ & $2.50^{\mathrm{a}}$ & 1.00 & $2.50^{\mathrm{a}}$ & 1.10 & $3.00^{\mathrm{b}}$ & 1.00 & 0.001 \\
\hline
\end{tabular}

\section{$\mathrm{IQR}=$ Interquartile Range}

P Kruskal-Wallis test value $(P<0.05)$.

a, b, c significant difference $(P<0.05)$ between the groups based on the $U$ Mann-Whitney test. Different letters indicate significant differences between groups.

The three groups presented statistically significant differences in four of the factors $(\mathrm{P}<0.001)$ : hedonism over health, practicality, stimulating function and black coffee and nostalgia. The Pragmatic and the Hedonic Dependent groups had similar results for territorial recognition, prestige and conservative taste $(\mathrm{P}<0.001)$. The Indifferent and Pragmatic groups had similar results for traditional taste and preference for mixed beverages $(\mathrm{P}<0.001)$. Regarding the denomination of origin, the results of the Pragmatic group differed from the results of the other two groups ( $\mathrm{P}<0.017)$.

As shown in Figure 2, Mexican coffee consumers gave low scores to most factors, although there are some variations between groups that allow the identification of different types of consumers.

Once the consumer groups were established, the socioeconomic information was analysed to determine which aspects influence the composition of the different groups.

The Indifferent and Pragmatic groups were almost equally divided in terms of gender, but in the Hedonic Dependent group, almost $60 \%$ were male (Table 5).

Regarding age, more than half of the consumers in the Indifferent group were young people under 25 years of age; in the Pragmatic group, almost half of the consumers were from that same age group, and the Hedonic Dependent group showed a slight tendency to concentrate middle-aged people (up to 45 years). In all groups, most people were single and without children, and had medium to high levels of education, but in the Hedonic Dependent group had even higher educational levels (university education).

Most of the participants were employed or had an independent job, especially those in the Hedonic Dependent group, which also had the lowest proportion of students.

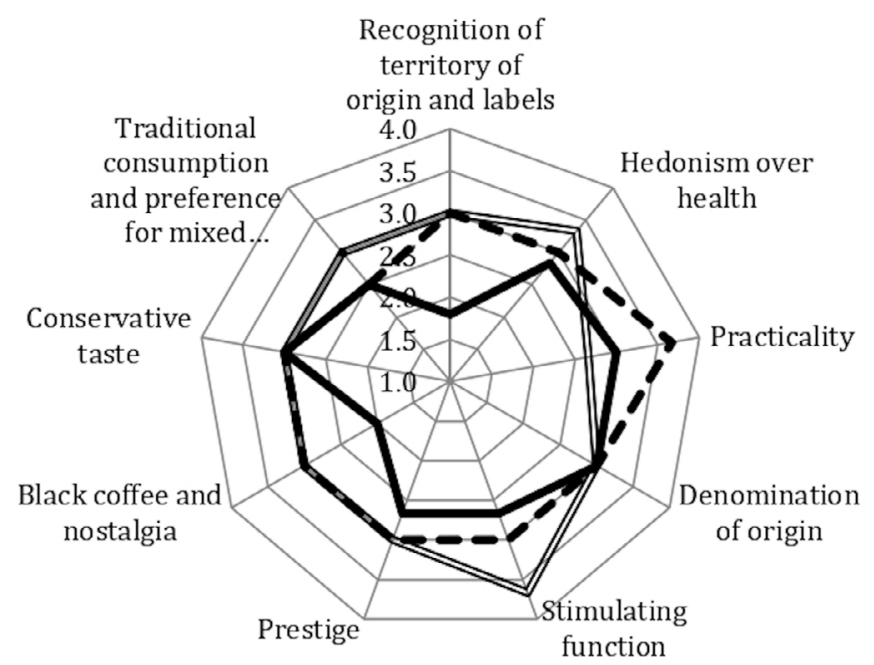

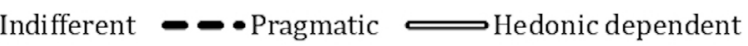

Figure 2: Characteristics of the groups of consumers identified according to the factors.

Consumers in the Indifferent group did not consume coffee regularly, while the Pragmatic group, and especially the Hedonic Dependent group, consumed coffee frequently (Table 6).

As mentioned before, the establishments where the questionnaires were applied sell products with various quality labels, would suggest that consumers are familiar with some of them. However, a very low proportion of consumers in the groups identified (less than 15\%) recognized the most common quality labels for coffee produced in Mexico: Denomination of Origin (Veracruz), Rain Forest and Fair Trade. The label "Made in Mexico", which was used as a control variable, was recognized by all consumers (Figure 3 ). 
Table 5: Sociodemographic characteristics of the identifies groups (\%).

\begin{tabular}{|c|c|c|c|c|}
\hline Variable & & Indifferent & Pragmatic & Hedonic Dependent \\
\hline \multirow{2}{*}{ Sex } & Men & 47.4 & 51.7 & 40.2 \\
\hline & Women & 52.6 & 48.3 & 59.8 \\
\hline \multirow{4}{*}{ Age } & $18-25$ & 54.9 & 48.9 & 42.4 \\
\hline & $26-45$ & 36.4 & 41.6 & 47.6 \\
\hline & $46-65$ & 8.1 & 9.0 & 10.0 \\
\hline & Older than 65 & 0.6 & 0.6 & 0.0 \\
\hline \multirow{4}{*}{ Educational level } & Without studies & 0.0 & 0.6 & 0.4 \\
\hline & Basic education & 11.0 & 6.7 & 4.4 \\
\hline & High school/Technical school & 49.1 & 55.1 & 40.6 \\
\hline & University & 39.9 & 37.6 & 64.6 \\
\hline \multirow{5}{*}{ Occupation } & Student & 34.9 & 33.3 & 26.0 \\
\hline & Employee/Independent & 57.0 & 57.1 & 68.3 \\
\hline & Housewife & 6.4 & 6.2 & 3.7 \\
\hline & Worker & 1.2 & 1.1 & 0.0 \\
\hline & Unemployed/retired & 0.6 & 2.3 & 2.0 \\
\hline \multirow{2}{*}{ Marital status } & Single/without compromise & 66.5 & 74.2 & 67.1 \\
\hline & Married & 33.5 & 25.8 & 32.9 \\
\hline \multirow{2}{*}{ Children } & Yes & 30.1 & 33.7 & 36.9 \\
\hline & No & 69.9 & 66.3 & 63.1 \\
\hline
\end{tabular}

Table 6: Consumption patterns of each group.

\begin{tabular}{|c|c|c|c|c|}
\hline Variables & Answers & Indifferent & Pragmatic & Hedonic Dependent \\
\hline \multirow{3}{*}{ Frequency of consumption } & Daily & 38.2 & 44.4 & $\mathbf{5 3 . 0}$ \\
\hline & $1-3$ per week & 32.4 & 28.1 & 38.2 \\
\hline & 1 time per month or less & 29.5 & 27.5 & 8.8 \\
\hline \multirow{4}{*}{ Preference during the day } & Morning & 35.3 & 28.1 & 21.3 \\
\hline & Afternoon & 11.8 & 20.8 & 14.1 \\
\hline & Night & 27.7 & 29.2 & 25.7 \\
\hline & Any time & 26.0 & 21.9 & 39.0 \\
\hline \multirow{4}{*}{ Place of consumption } & At home & 57.8 & 36.5 & 42.2 \\
\hline & Coffee shops & 14.5 & 32.0 & 28.1 \\
\hline & At work & 16.2 & 26.4 & 15.3 \\
\hline & Other & 4.6 & 3.4 & 1.2 \\
\hline & Various places & 6.9 & 1.5 & 13.3 \\
\hline \multirow{3}{*}{$\begin{array}{l}\text { Frequency of visits to coffee } \\
\text { shops }\end{array}$} & Daily & 6.4 & 11.2 & 15.3 \\
\hline & 1-3 times per week & 23.1 & 39.9 & 47.0 \\
\hline & 1 time per month or less & 70.1 & 48.9 & 37.8 \\
\hline \multirow{5}{*}{$\begin{array}{l}\text { People with whom you meet in } \\
\text { coffee shops }\end{array}$} & Family/ Spouse/ Partner & 27.7 & 20.2 & 21.8 \\
\hline & Friends & 34.4 & 38.8 & 44.4 \\
\hline & Work colleagues & 12.1 & 18.0 & 12.5 \\
\hline & Nobody & 13.3 & 21.9 & 9.3 \\
\hline & Various people & 10.4 & 1.1 & 12.1 \\
\hline
\end{tabular}




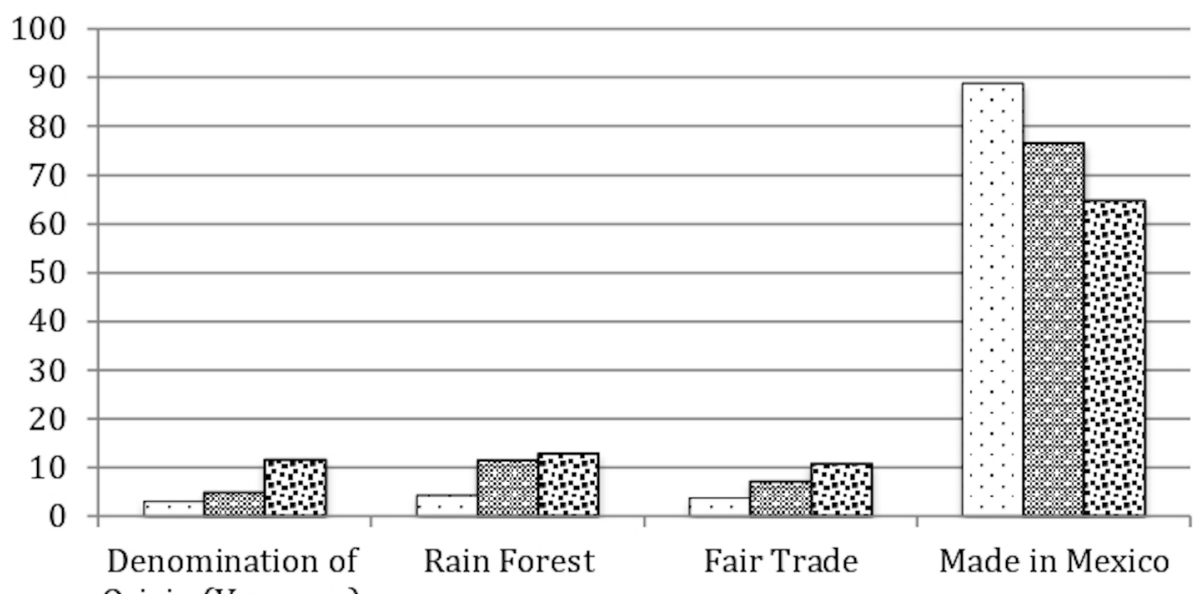
Origin (Veracruz)

\section{$\square$ Indifferent $\quad$ Pragmatic M Hedonic Dependent}

Figure 3: Knowledge of quality labels by group (\%).

\section{DISCUSSION}

Factor analysis establishes how the variables are grouped. The ethical aspects of coffee production or the link of a product with a territory in the Factor 1, are widely studied aspects in coffee consumers in different parts of the world (Pelsmacker; Driesen; Raypdo, 2005; Macchione; Eugênio, 2006; Teuber; Herrmann, 2012; Jang; Kim; Lee, 2015; Van Loo et al., 2015), which is logical for a product that is widely marketed on a global scale and for which labels are a referent of quality.

In this study, hedonism and perceptions of health were mixed; however, this has not happened in other works. hedonism is undoubtedly a widely reported aspect in studies on food consumption (Spinelli et al., 2013; Jiménez et al., 2014; Zurawicki, 2015). Specific studies on coffee have focused on taste, aroma and visual attractiveness (Varela; Beltrán; Fiszman, 2014; Labbe et al., 2015; Van Loo et al., 2015), as well as hedonic aspects related to the transformation process such as roasting and instantaneous preparation (Shinoda et al., 2015), and even on flavouring with milk beverages (Li; Hayes; Ziegler, 2014) or sugar (Varela; Beltrán; Fiszman, 2014).

Regarding the health effects of coffee, Cano, Tarín and Cano (2013) mentioned the risks of drinking coffee for the gastrointestinal tract, but there is no clear agreement in the scientific literature. The papers on the subject suggest there is no evidence that moderate consumption of three to four cups of coffee a day generates health risks; on the contrary, it seems to have some health benefits. However, consumers with predisposing factors may be more vulnerable to the negative effects of coffee (Higdon; Frei, 2006). Specific works on the gastrointestinal system mention that the consumption of coffee produces gastroesophageal reflux, although though they do not relate it to dyspepsia (gastritis) (Boekema et al., 2009).
Respecting practicality, is a common variable in other studies of food products (Gaviglio et al., 2014). In the case of coffee, the most important aspect has been the place of purchase (Chen; $\mathrm{Hu}, 2010$ ).

It is interesting that items related to the effect of the product on the organism and a hedonic element turned out to be associated. Labbe et al. (2015) differentiate between hedonic and utilitarian functions, which are mixed in the present work. The stimulating function is a well-known feature of coffee, several studies have focused on the influence of caffeine on drowsiness (Pelsmacker et al., 2005; Roehrs; Roth, 2008; Labbe et al., 2015).

Prestige factor could have been named "economic aspects"; however, given that the willingness to buy expensive and specialty coffee highlights the purchasing power of consumers, it was called Prestige. The perception of the economic value of coffee is a variable that was studied by Chen and $\mathrm{Hu}$ (2010) with respect to Australian coffee consumers, and by Kang et al. (2012) and Van Loo et al. (2015) in US consumers.

Many studies have found that economic aspects are a fundamental factor in the consumption of food products (Lange et al., 2015; Espinoza-Ortega et al., 2016); however, in the present study the economic aspects were not important, and the item that included the buying of low-priced coffee had to be eliminated given its low explanatory power (Table 1).

The influence of emotional states on food choice and eating behaviour have been extensively studied, and this has made it possible to understand the role of food on alleviating unpleasant sensations (Köster; Mojet, 2015). Specific studies on coffee have analysed this variable (Tumanan; Lansangan, 2012), including nostalgia (considered a negative feeling) using emotional maps (Labbe et al., 2017). 
Related to the lack of interest in looking for different products, the intention of purchase is a crucial variable in this type of studies (Kang et al., 2012), especially when considering quality labels (Macchione; Eugênio, 2006; Lange et al., 2015).

Undoubtedly, the appearance of global brands and their tendency to sell coffee in mixed beverages has helped increase the popularity of coffee. Hence the increasing amount of consumer choice related to mixed beverages (Varela; Beltrán; Fiszman, 2014; Asioli et al., 2015; Jang; Kim; Lee, 2015), as shows Factor 9.

The results of factor analysis were used to perform the cluster analysis, which grouped the persons interviewed. Group one gave the lowest scores to all the factors; they oscillate between indifference and giving little or null importance to the variables studied. It gave the lowest scores even to the factor linked to hedonism. That is why this group was named Indifferent. This group represents $28.8 \%$ of the sample.

It is also the group that attributed the lowest value to aspects related to the emotions associated with consuming coffee, which was summed up in Factor 7 black coffee and nostalgia. Some studies have established the importance of evoking positive emotions when choosing food (Gutjar et al., 2014). Perhaps the value attributed to the association of nostalgia with coffee was so low because nostalgia is a negative emotion.

The Pragmatic group, which had $29.6 \%$ of the respondents, did not give high scores to most of the factors, except for practicality, which is why it was named that way. Consumers in this group attributed the lowest value to the stimulating function, traditional taste and preference for mixed beverages.

The group considered as Hedonic Dependent was the most numerous, with $41.5 \%$ of the respondents. This group gave the highest scores to most factors, standing out from the other groups by the high scores given to the stimulating function and because the values hedonism over health. By contrast, this group gave the lowest score to practicality (Figure 1).

The work of Labbe et al. (20015) established that consumers who look for the stimulating effect find the experience of drinking coffee less pleasant than those whose main interest is sensory satisfaction. This is completely opposite to what was found in the present work, in which the Hedonic Dependent group gave a high score to the stimulating function of coffee as well as to its aroma, combining utilitarian and hedonic interests; this seems even more interesting when one considers that this group prioritized these aspects over health and practicality.

The Socio-economic information shows that two groups were almost equally divided in terms of gender, but only the Hedonic Dependent group were more male (Table 5), This contrasts with other studies in which the sample of respondents were formed mostly by women (Pelsmacker; Driesen; Raypdo, 2005; Asioli et al., 2015; Jang; Kim; Lee, 2015; Van Loo et al., 2015).

Despite the slight differences of age between groups, it can be concluded that the consumers who buy coffee in the stores studied here are between 18 and 45 years old, which agrees with what has been found in other studies (Pelsmacker; Driesen; Raypdo, 2005; Kang et al., 2012; Jang; Kim; Lee, 2015; Van Loo et al., 2015, Sepúlveda et al., 2016).

The work of Asioli et al. (2015) reports differences in the preference for different types of coffee according to age. Young consumers show a tendency to buy coffee products mixed with milk, while older consumers tend to buy espresso. Although the present study did not aim to identify the preferences of consumers for different types of coffee, it found that the Indifferent group, which concentrated the highest proportion of young people, gave low scores to the factors related to black coffee and mixed coffee beverages.

Age is associated with the variable of marital status and to the presence of children. In all groups, most people were single and without children (Table 5). It should be noted that few studies consider the variable of children. One of them is the study by Van Loo et al. (2015), in which more than half of the consumers studied had children.

Regarding the educational level of the respondents, the study herein reported also differs from others, most of consumers had medium to high levels of education, and in the Hedonic Dependent group had even higher educational levels (university education). This coincides with the studies of Pelsmacker, Driesen and Raypdo, (2005) and Van Loo et al. (2015), but in other studies most coffee consumers were not college educated (Jang; Kim; Lee, 2015; Sepúlveda et al., 2016).

Undoubtedly, the educational level of person is a major determinant of his/her occupation. In the three groups of consumers identified in this work, most of the participants were employed or had an independent job, especially those in the Hedonic Dependent group, which also had the lowest proportion of students. Workers, housewives, unemployed and the retired were little represented in all groups; most of the respondents were involved in professi onal activities, which coincides with what has been found in other works (Pelsmacker; Driesen; Raypdo, 2005; Asioli et al., 2015; Jang; Kim; Lee, 2015).

Regarding the preference for a place of consumption, the consumers in the Indifferent and Hedonic Dependent groups preferred to consume coffee at home, but in the Pragmatic group had no preference for any particular place. Undoubtedly, economic independence, singleness and the absence of children influence the frequency of visits to establishments that sell coffee in cups. The highest frequency was found in the Hedonic Dependent group, since almost 
half of the consumers visited coffee shops very frequently. In contrast, in the Indifferent group they visit coffee shops only once a month or less. Everything seems to indicate that consumers visit coffee shops to socialize, since most participants in all groups preferred to go to coffee shops with friends, family or spouse/partners. Thus, coffee and its quality seem to be the least important aspect in the decision to visit these establishments.

In this regard, Bangcuyo et al. (2014) state that the consumption of coffee in coffee shops is strongly linked to positive emotions and a rewarding social experience, such as spending time with friends or relaxing. There is also interest in emulating the habits or lifestyle of others (Kang et al., 2012). Thus, it can be said that people go to coffee shops not to buy coffee but to buy an experience (Tumanan; Langsangnan, 2012).

The low interest of Mexican consumers in the quality of coffee is reflected in the knowledge of quality labels (Figure 3). Several authors mention that consumers are increasingly concerned about the quality of the products they ingest and about their origin and the processes to which they have been subjected, showing a growing interest in labels as a basic mechanism for accessing this information (Macchione; Eugênio, 2006; Verbeke et al., 2012; Lozano et al., 2013); however, the consumers who participated in this study were not interested in these aspects.

This is not exclusive to Mexico. Studies done in other countries with consumers of coffee show that the most important factor in the decision to buy is the brand, then taste and finally quality labels related to ethical or territorial aspects (Pelsmacker et al., 2005; Macchione; Eugenio, 2006).

However, Jang, Kim and Lee (2005) found that green practices had a significant influence on the consumers' attachment to a particular store, which means that the role of the companies in promoting these quality labels is crucial (Kang et al., 2012), especially when considering the negative environmental effects of some production practices (Jurjonas et al., 2016). In this regard, Lange et al. (2015) mention that consumers who are exposed to ethical information increase their interest in buying ethical products.

The importance of quality labels for private companies cannot be understated, since in many cases it is through these labels (Macchione; Eugênio, 2006: Lange et al., 2015) that small producers have access to the market (Sepúveda et al., 2016).

\section{CONCLUSIONS}

Nine factors and three groups of consumers were identified; the consumers in all groups gave low scores to the nine factors identified. The groups differed in the importance they gave to pragmatic aspects, the stimulating and hedonic function of coffee, and in their general lack of interest for the differentiating attributes of coffee. Hence, the groups were named as Indifferent, Pragmatic and Hedonic Dependent. The consumers of coffee who participated in this study were mostly young and middle-aged, single, childless and college educated. Their main interest in attending coffee shops is to socialize. They showed a total lack of knowledge about quality labels, which has negative implications for the implementation of this type of labels in Mexico. Thus, perception of the consumer and a promotion strategy should be considered by the coffee production sector for an adequate development of quality seals for Mexican consumers.

\section{ACKNOWLEDGEMENTS}

This work was undertaken thanks to funding by the Mexican National Council for Science and Technology (Consejo Nacional de Ciencia y Tecnología - CONACYT) through grant number 220531CB-2013. Angélica EspinozaOrtega is principal investigator and corresponding author.

\section{REFERENCES}

AGUILAR, B. S. Formulas para el cálculo de la muestra en investigaciones de salud. Salud en Tabasco, 11(1-2):333$338,2005$.

ANDERSON, R. D.; SWEENEY, J. D.; WILLIAMS. A. T. Estadística para administración y economía. $10^{\mathrm{a}} \mathrm{ed}$. México: Cengage Learning, 2008. 1091p.

ARAGÓN, G. C. et al. Evaluación del valor percibido en el consumo de café con atributos éticos. Agrociencia, 47(2):195-207, 2013.

ASIOLI, D. et al. Comparison of rating-based and choicebased conjoint analysis models. A case study based on preferences for iced coffee in Norway. Food Quality and Preference, 48(part A):174-184, 2015.

BANGCUYO, R. C. et al. The use of immersive technologies to improve consumer testing: The role of ecological validity, context and engagement in evaluating coffee. Food Quality and Preference, 41:84-95, 2014.

BOEKEMA, P. J. et al. Coffee and Gastrointestinal Function: Facts and fiction: A review. Scandinavian Journal of Gastroenterology, 34(230):25-39, 1999.

CANO, M. A.; TARÍN, J. J.; CANO, A. The impact of coffee on health. Maturitas, 75(1):7-2, 2013.

CHEN, P. S.; HU, H. H. The effect of relational benefits on perceived value in relation to customer loyalty: An empirical study in the Australian coffee outlets industry. International Journal of Hospitality Management, 29(3):405-412, 2010. 
CLEMONS, E. K. How information changes consumer behaviour and how consumer behaviour determines corporate strategy. Journal of Management Information Systems, 25(2):13-40, 2008.

DE OLIVEIRA, S. D. et al. Consumidor de café expresso em minas gerais: Diferenças, hábitos e preferências. Gestão \& Regionalidade, 28(84):49-60, 2012.

DONOVAN, J.; POLE, N. Changing asset endowments and smallholder participation in higher value markets: Evidence from certified coffee producers in Nicaragua. Food Policy, 44:1-13, 2013.

ECKHARDT, M. G.; BELK, R.; DEVINNEY, M. T. Why don't consumers consume ethically? Journal of Consumer Behaviour, 9(6):426-436 2010.

ELORRIAGA, N. et al. ¿Qué factores influyen en la elección de alimentos de los estudiantes de Ciencias de la Salud? Diaeta, 30(141):6-24, 2012.

ESPINOZA-ORTEGA, A. et al. Motives for food choice of consumers in Central Mexico. British Food Journal, 118(11):2744-2760, 2016.

FIELD, D. Discovering statistics using SPSS. England: SAGE, 2009. 821p.

FOOD AND AGRICULTURE ORGANIZATION OF THE UNITED NATIONS - FAO. Estudio sobre los principales tipos de sellos de calidad en alimentos a nivel mundial. Estado actual y perspectivas de los sellos de calidad en productos alimenticios de la agroindustria rural en América Latina. 2002. Santiago de Chile: Available in: <http://www.alimentosargentinos.gob.ar/ contenido/publicaciones/calidad/BPM/diferenciacion/ sellosdecalidadFAO.pdf $>$. Access in: August 27, 2020.

FOTOPOULOS, C. et al. Food Choice Questionnaire (FCQ) revisited Suggestions for development of an enhanced general food motivation model. Appetite, 52(1):199-208, 2008.

GAVIGLIO, A. et al. Consumer perception of different species and presentation forms of fish: An empirical analysis in Italy. Food Quality and Preference, 36:3-49, 2014.

GIOVANNUCCI D.; LIU, P.; BYERS, A. Value-adding standards in the North American food market-trade opportunities in certified products for developing countries. Roma: FAO, 2008. 303p.

GONZÁLEZ, M. E.; RAMÍREZ, M. M. V. Impact of caffeine and coffee on our health. Trends in Endocrinology and Metabolism, 25(10):89-492, 2014.
GOTOW, N. et al. High consumption increases sensitivity to after-flavour of canned coffee beverages. Food Quality and Preferences, 44:162-171, 2015.

GUERRERO, L. et al. Consumer-driven definition of traditional food products and innovation in traditional foods. A qualitative cross-cultural study. Appetite, 52(2):345-354, 2009.

GUTJAR, S. et al. The role of emotions in food choice and liking. Food Research International, 76(Part 2):216223, 2014.

HAIR, J. F. et al. Multivariate Data Analysis. London: Prentice Hall International, 2009. 785p.

HIGDON, J. V.; FREI, B. Coffee and Health: A review of recent human research. Critical Reviews in Food Science and Nutrition, 46(2):101-123, 2006.

IBARRA, V. Escenarios metropolitanos de la movilidad cotidiana. Desarrollo urbano y regional", In: GARZA, G.; SCHTEINGART, M. Los grandes problemas de México II Desarrollo Urbano y Regional. México: El colegio de México, 2010, p.449-510.

INSTITUTO MEXICANO DE LA PROPIEDAD INDUSTRIAL - IMPI. Declaratoria general de Protección a la Denominación de origen "Café Veracruz". 2000. Available in: <http:/www.wipo.int/ wipolex/es/text.jsp?file_id=220957>. Access in: August 27,2020 .

INSTITUTO MEXICANO DE LA PROPIEDAD INDUSTRIAL - IMPI. Declaratoria general de Protección a la Denominación de origen "Café Veracruz". 2003. Available in: <http://www.wipo.int/ wipolex/es/text.jsp?file_id=220957>. Access in: August 27,2020 .

INTERNATIONAL COFFEE ORGANIZATION - ICO. Country Data on the Global Coffee Trade, ICO, London, England. 2015. Available in: <http://www.ico. org/profiles_e.asp>. Access in: August 27, 2020.

JANG, J. Y.; KIM, G. W.; LEE, Y. H. Coffee shop consumers' emotional attachment and loyalty to green stores: The moderating role of green consciousness. International Journal of Hospitality Management, 44:46-156, 2015.

JIANG, Y.; KING, J. M.; PRINYAWIWATKUL, W. A review of measurement and relationships between food, eating behaviour and emotion. Trends in Food Science \& Technology, 36(1):5-28, 2014. 
JIMÉNEZ, M. et al. Seeing a meal is not eating it: Hedonic context effects differ for visually presented and actually eaten foods. Food Quality and Preference, 41:96-102, 2014.

JURJONAS, M. et al. Potential link between certified organic coffee and deforestation in a protected area in Chiapas, Mexico. World Development, 78:13-21, 2016.

KANG, J. et al. Understanding customer behaviour in name-brand Korean coffee shops: The role of selfcongruity and functional congruity. International. Journal of Hospitality Management, 31(2):809-818, 2012.

KÖSTER, E. P.; MOJET, J. From mood to food and from food to mood: A psychological perspective on the measurement of food-related emotion in consumer research. Food Research International, 76(Part 2):80191, 2015.

LABBE, D. et al. Pleasantness, emotions and perceptions induced by coffee beverage experience depend on the consumption motivation (hedonic or utilitarian). Food Quality and Preference, 44:56-61, 2015.

LANGE, C. et al. Impact of information and in-home sensory exposure on liking and willingness to pay: The beginning of fairtrade labelled coffee in France. Food Research International, 76(Part 3):317-324, 2015.

LI, B.; HAYES, E. J.; ZIEGLER, R. G. Interpreting consumer preferences: Physicohedonic and psychohedonic models yield different information in a coffee-flavored dairy beverage. Food Quality and Preference, 36:27-32, 2014.

LINTON, M. L. A. Fair trade: A cup at a time? Politics and Society, 31(3):407-432, 2003.

LOZANO, C. et al. Las etiquetas alimentarias: ¿Herramientas de (Des) Conexión entre productores y consumidores? Respuestas alimentarias a la crisis económica, XI Congreso Español de Sociología. In: CAIRO, H.; FINKEL, L. Crisis y cambio: Propuestas desde la Sociologia. España: Universidad Complutense de Madrid, 2013, p.1195-1204.

MACCHIONE, S. M. S.; EUGÊNIO, S. E. Percepção do consumidor sobre los atributos de diferenciação no segmento rural: café no mercado interno. Organizações Rurais \& Agroindustriais, 8(3):354-367, 2006.

MARTÍNEZ, R. J. Los tamaños de muestras en encuestas de las ciencias sociales y su repercusión en la generación del conocimiento. Innovaciones de negocios, 11(22):235$268,2014$.
MASSON, M. et al. Beyond sensory characteristics, how can we identify subjective dimensions? A comparison of six qualitative methods relative to a case study on coffee cups Food Quality and Preference, 47(Part b):156-165, 2016.

MEISELMAN, H. I. A review of the current state of emotion research in product development. Food Research International, 76(Part2):192-199, 2015.

NEGRETE, S. M. E. Las metrópolis mexicanas: Conceptualización, gestión y agenda de políticas. Desarrollo urbano y regional. In: GARZA, G.; SCHTEINGART, M. Los grandes problemas de México. II desarrollo urbano y regional. México: El colegio de México, 2010, p.173-212.

PELSMACKER, P.; DRIESEN, L.; RAYPDO, G. Do Consumers Care about Ethics? Willingness to Pay for Fair-Trade Coffee. The Journal of Consumer Affairs, 39(2):363-385, 2005.

PIENIAK, Z. et al. Association between traditional food consumption and motives for food choice in six European countries. Appetite, 53(1):101-108, 2009.

ROEHRS, T.; ROTH, T. Caffeine: Sleep and daytime sleepiness. Sleep Medicine Reviews, 12(2):53-162, 2008.

SECRETARÍA DE AGRICULTURA, GANADERÍA, DESARROLLO RURAL, PESCA Y ALIMENTACIÓN SAGARPA. Café de México. 2002. Available in: < https:// datos.gob.mx/busca/dataset?q $>$. Access in: August 21, 2020 .

SCHUBERT, M. M. et al. Coffee for morning hunger pangs. An examination of coffee and caffeine on appetite, gastric emptying, and energy intake. Appetite, 83:317-326, 2014.

SEPÚLVEDA, W. S. et al. Consumer preference for the origin and quality attributes associated with production of speciality coffees: Results from a cross-cultural study. Food Research International, 89(Part 2):997-1003, 2016.

SHIFFMAN, G. L.; LAZAR, K. L.; WISENBLIT, J. Comportamiento del consumidor. 10th ed. México: Pearson Education, 2010. 592p.

SHINODA, M. et al. Inverse relationship between coffee consumption and cerebral micro bleeds in men, but not women. Journal of Stroke and Cerebrovascular Diseases, 24(10):2196-2199, 2015.

SPINELLI, S. et al. How does it make you feel? A new approach to measuring emotions in food product experience. Food Quality and Preference, 37:109-122, 2014. 


\section{STATGRAPHICS CENTURION X. Statgraphics}

Technologies, Inc. Computer Software. The Plains, Virginia, 2015. Available in: $<$ https://www.statgraphics. com/>. Access in: August 21, 2020.

STEPTOE, A.; POLLARD, T. M.; WARDLE, J.

Development of a measure of the motives underlying the selection of food: The food choice questionnaire. Appetite, 25:267-84, 1995.

SUNARHARUM, B. W.; WILLIAMS, J. D.; SMYTH, E. H. Complexity of coffee flavour: A compositional and sensory perspective. Food Research International, 62:315-325, 2014.

TEUBER, R.; HERRMANN, R. Towards a differentiated modelling of origin effects in hedonic analysis: An application to auction prices of specialty coffee. Food Policy, 37(6):32-740, 2012.

TUMANAN, R. A. M.; LANSANGAN, G. R. J. More than just a cup of coffee: A multi-dimensional approach towards analysing the factors that define place attachment. International Journal of Hospitality Management. (3192):529-534, 2012.
UNITED STATES DEPARTMENT OF AGRICULTURE USDA. USDA Accredited Certifying Agents (ACAs), 2013 List of certified USDA organic operations. 2014. Available in: <https://www.ams.usda.gov/resources/ organic-certifying-agents $>$. Access in: August 27, 2020.

VAN LOO, J. E. et al. Sustainability labels on coffee: Consumer preferences, willingness-to-pay and visual attention to attributes. Ecological Economics, 118:15$225,2015$.

VARELA, P.; BELTRÁN, J.; FISZMAN, S. An alternative way to uncover drivers of coffee liking: Preference mapping based on consumers' preference ranking and open comments. Food Quality and Preference, 32(Part b):152-159, 2014.

VERBEKE, W. et al. Consumers awareness and attitudinal determinants of European Union Quality Label use on traditional foods. Bio-based and Applied Economics, 1(2):213-229, 2012.

ZURAWICKI, L. Pleasures of the palate from the consumer marketing perspective. Food Research International, 76(Part 2):200-206, 2015. 